\title{
COMMENTS ON THE DEFINITION OF THE ORDOVICIAN-SILURIAN BOUNDARY
}

In recent years, progress has been observed in the investigation of the Ordovician-Silurian boundary and correlation of the boundary sections all over the world. Under the guidance of a special working group, discussions on the system boundary are approaching the final stage. As for the definition of the boundary, we are faced with the choice of a faunal group (graptolites or conodonts), zonal level (persculptus, acuminatus, oldhamensis), and stratotype (South Scotland, or Anticosti). Many workers studying the comparative biostratigraphic data use the Kazakhstan evidence concerning the co-occurrences of the benthic association of the Hirnantia type and the persculptus Zone graptolites, which have been discovered there (Граница ордовика..., 1980). Now some contradictions in estimating data on the Kazakhstan graptolite occurrences have come to light. This fact obliges us to return to that problem and, using likewise the corresponding new evidence on Northeast USSR, clear up some points which seem disputable, and express our opinion on the above boundary.

In 1969 N. Mikhailova identified for the first time Glyptograptus persculptus (Salter) from the beds now assigned to the lower part of the Durben Regional Stage (Граница ордовика..., 1980, exp. Н-66, Fig. 7). At that time two specimens were sent to R. B. Rickards, who approved the identification (Михайлова, 1970, 1973). Later graptolites were collected from several localities and at different stratigraphical levels within the Durben Regional Stage. When examining all the collections from the lower part of the Durben Regional Stage, from where G. ? persculptus was earlier reported (exp. H-66), T. Koren and her colleagues described $G$. ? persculptus forma A and $G$. ? aff. persculptus (Salter) (Граница ордовика..., 1980, Fig. 7). The newly found graptolites from the middle and upper parts of the Durben Regional Stage were assigned to $G$. ? persculptus forma B. There was mentioned «a close morphological similarity in the rhabdosome and thecal shape in G. ? persculptus forma A and Climaeograptus ? extraordinarius group from the Tirekhtjakh Regional Stage in Northeast USSR» (Граница ордовика..., 1980, p. 149). The latter is represented in the Kolyma collections by flattened and often deformed specimens as compared with the 3-D specimens in Kazakhstan. The different state of preservation of the specimens makes it extremely complicated to define these morphologically simple and similar diplograptids with no clear diagnostic features, such as thecal spines, etc.

Using the type material from the Ina River section in Northeast USSR, T. Koren and R. Sobolevskaya concluded the identity of C. ? extraordinarius and $G$. ? persculptus forma $A$ as well as $G$. ? aff. persculptus. This enabled them to correlate the lower part of the Durben Regional Stage with the $Q$ member on the Mirny Creek. At the same time the identity of G.? persculptus forma B and Glyptograptus bohemicus 
Marek was discovered by T. Koren when comparing the Kazakhstan species with the original photographs (type series) and a latex copy of a specimen in relief (Pancrač) of $G$. bohemicus kindly sent by L. Marek. In addition, the study also included numerous specimens of $G$. bohemicus from the type locality (Praha-Nova-Ves), collected by I. Nikitin jointly with L. Marek. Comparison of $G$. ? persculptus forma B and $G$. bohemicus Marek with $G$. ? persculptus (Salter), received on loan from R. B. Rickards (Wales, Abergwesyn) and collected from the Upper Tirekhtjakh Regional Stage allowed the assignment of all the above-mentioned forms to the species $G$. ? persculptus (Salter) (Граница ордовика..., 1980, p. 146, see synonymy). The specimens assigned to $G$. bohemicus Marek and $G$. ? persculptus (Salter) are identical in the thecal shape, degree of genicular curvature and in the inclination of the supragenicular wall, in the position of the base of the median septum and in the rhabdosome size, as well as in thecal frequency. The results of investigations including the identity of $G$. ? persculptus forma $\mathrm{A}$ and C. ? extraordinarius as well as $G$. ? persculptus forma B, G. bohemicus Marek and G. ? persculptus (Salter) were demonstrated to R. B. Rickards who agreed to these conclusions (Rickards, Riva, 1981, p. 226). So, the concept of the identity of $G$. ? persculptus in Kazakhstan with C. ? extraordinarius (Rickards, 1982, personal communication to T. Koren) is correct only so far as G. ? persculptus forma A (Граница ордовика ..., 1980, p. 147, Pl. XLII, Figs 3-6; Pl. XLIII, Fig. 1; Pl. XLIV, Figs 1-6; Text-Fig. 44, a-k) and $G$. ? aff, persculptus (p. 151, P1. XLVII, Figs $1-3$ ) are concerned. The identification of $G$. ? persculptus forma B (P1. XLV, Figs $1-6$; P1. XLVI, Figs $1-8$; Text-Fig. 45 a-ж) and $G$. ? persculptus (Salter) from Great Britain does not arouse any doubt.

Unlike in Great Britain, the Hirnantia fauna in the Ordovician-Silurian boundary sections in Kazakhstan and Northeast USSR is not confined to the extraordinarius Zone alone, but goes through the whole persculptus Zone. It is worth mentioning that the richest and most typical Hirnantia fauna occurs in association with $G$. ? persculptus (Salter) (=G. ? persculptus forma B; Граница ордовика..., 1980, Fig. 7, exp. 287) but not with $C$. ? extraordinarius (Sob.) (=G. ? persculptus forma A and $G$. ? aff. persculptus, 1980).

In the sections studied in Northeast USSR (Граница ордовика...., in print), the stratigraphical interval of the Hirnantia beds (member Q on the Mirny Creek) coincides with two graptolite zones - extraordinarius and persculptus, as established by $M$. Oradovskaya. On the Mirny Creek and Neznakomka River, the highest-lying Hirnantia fauna was found at $3-5 \mathrm{~m}$ below the base of the acuminatus-ascensus Zone. Along the Mirny Creek the richest Hirnantia fauna is associated with $G$. ? persculptus in the lower part of the eponymous Zone, $27 \mathrm{~m}$ thick. In the uppermost part of this zone, $15 \mathrm{~m}$ thick, as well as in the underlying extraordinarius Zone, there occur single representatives of the characteristic brachiopod assemblage. The boundary of the Hirnantia and Skenidioides beds coincides with that of persculptus and acuminatus (Граница ордовика..., in print).

Within the extraordinarius and persculptus Zones trilobites belonging to Dalmanitina and Mucronaspis were identified by M. Apollonov and M. Chugayeva. They are typical of the late Ordovician Dalmanitina association and unknown in the section studied from both underlying and overlying beds. In the Mirny Creek and Kharkindzha River sections, the highest occurrences of Dalmanitina olini Temple and Dalmanitina sp. indet. are $1-3 \mathrm{~m}$ below the base of the acuminatus-ascensus Zone, together with the last $G$. ? persculptus (Salter). A new trilobite Acer- 
naspis fauna was found for the first time $0.2-0.3 \mathrm{~m}$ above the base of the acuminatus-ascensus Zone coinciding with the lower boundary of the Chalmak Regional Stage.

Many researchers assume that one of the zonal boundaries in the graptolite sequence should be used in defining the level of the standard boundary of the systems. If the base of the persculptus Zone is used as the Ordovician-Silurian boundary, its definition according to the appearance of zonal species will present great difficulties. Species Glyptograptus ? ojsuensis Kor. et Mikh. (the uppermost part of the supernus Zone), C. ? extraordinarius (Sob.), C. ? ex gr. extraordinarius (the eponymous Zone), and $G$. ? persculptus occur in chronological succession in Northeast USSR and in Kazakhstan. In China, G. ? ojsuensis, C. ? extraordinarius (open nomenclature), and Diplograptus orientalis seem to have broader stratigraphical ranges in the Ordovician-Silurian boundary sections, having been recorded from the uppermost DiceratograptusParaorthograptus, bohemicus, and persculptus Zones. The latter two are characterized by almost identical graptolite assemblages. Such contradictions have most probably been caused by the different mode of preservation of specimens and different taxonomic approach in the identification of morphologically similar diplograptids. The graptolites known from the extraordinarius and persculptus Zones badly need a taxonomic revision. Their identifications made in different regions show that one and the same form can be assigned to different species, to say nothing of their generic assignment: Glyptograptus, Climatograptus or Diplograptus. With the above in view, Acad. B. Sokolov suggested during the Ordovician-Silurian boundary meeting held in Khabarovsk in 1979 that R. B. Rickards and T. Koren might make such a revision; however, that revision has not yet been completed. So now it is premature to make any definite time correlations of the $G$. ? persculptus beds in different regions in anticipation of a good potential for the further subdivision of the eponymous zone in the long turn.

Today only a general correlation of beds assigned to the persculptus Zone in different regions is possible. There is a limited number of sections with an exactly known range of $G$. ? persculptus, where a continuous succession with the underlying extraordinarius Zone can be established. If we take into account the experience of the Silurian-Devonian boundary definition and consider the geographical extent of the level chosen as an important criterion, then the zonal boundary between the extraordinarius and persculptus Zones does not seem to fit the definition both in the graptolite and the shelly strata.

As far as evolutionary changes in graptolites are concerned, the importance of the zonal boundary is inferior to that of the base of both the extraordinarius and acuminatus Zones. The persculptus Zone assemblage is not richer than the assemblage in the preceding extraordinarius Zone, and it is dominated by transient graptolite species. A single occurrence of Monograptus ceryx Rick. et Hutt (Rickards, Hutt, 1970), considered now as the oldest monograptid (in the persculptus Zone) cannot confirm the conclusion that this zone heralds the subsequent Llandovery evolutionary explosion. Monograptids are extremely rare in the succeeding acuminatus Zone, and they become an important element of graptolite associations starting from the base of the vesiculosus Zone, earlier discussed (Elles, 1922) as a possible Ordovician-Silurian boundary level.

There is no doubt as to the reliable definition of the base of the acuminatus Zone owing to the clear-cut evolutionary and morphological changes in graptolite associations traceable almost throughout the world. This is marked by the synchronous appearance of Akidograptus ascensus 
and Parakidograptus acuminatus in the sections (Kazakhstan, Central Asia and other areas). The beginning of akidograptid successions either with $A$. ascensus or with $P$. acuminatus in some sections does not imply the different chronological appearance of these diagnostic akidograptid species, and can most probably be explained by the incompleteness of sampling.

A peculiar assemblage of shelly fossils was recently discovered in Northeast USSR at the base of the acuminatus-ascensus Zone (the base of the Chalmak Regional Stage, beds with Skenidioides and Acernaspis; Орадовская, Соболевская, 1979; Корень et al., 1979; Граница ордовика..., in print). The representative shelly fauna dated by the acuminatus Zone graptolites is unknown elsewhere. However, in the persculptus Zone J. E. Hutt (1974) referred to the occurrences of abundant shelly fauna (brachiopods, trilobites, crinoids, etc.) in the western English Lake District, Yewdale Beck section including Kayserella (sensu Temple), Kinnella, Ravozetina and Paromalomena (Brenchley, Cocks, 1982). Kayserella also nccurs in the Ojsu limestones in Kazakhstan as Enteletacea gen. et sp. indet.; the uppermost part of the supernus Zone (Граница ордовика..., 1980, p. 44, Pl. X, Figs 13-15).

\section{Conclusions and recommendations}

A. Up to now there are no new data which cast doubt on the coincidence of the Dalmanitina-Hirnantia stratigraphical range with the extraordinarius and persculptus Zones, established in Kazakhstan and Northeast USSR.

B. The advantages of the base of the acuminatus Zone as a boundary of the Silurian system are obvious from the point of view of evolutionary, morphological and geographical criteria. Its practical use within extensive areas is not to be discarded.

C. The boundary between extraordinarius and persculptus Zones should not be proposed for a boundary of systems on the following grounds: 1) it is known from single continuous graptolite sequences; 2) it provides difficulties in definition due to the ambiguity of morphological criteria and similarity in the composition of extraordinarius and persculptus zonal assemblages; 3) it involves no representative shelly fauna.

D. A choice of a stratotype with zonal graptolite control is quite enough for the present detailed correlation of sections represented by different facies. The preference should be given to Dob's Linn section, where new graptolite and shelly faunas have been recently found by J. K. Ingham. The Mirny Creek section in Northeast USSR is proposed as a hypostratotype. The final decision concerning the level and stratotype of the Ordovician-Silurian boundary is to be made together with the definition of the name and type area of the first Silurian series. In this case the traditionally used Llandovery of Great Britain seems to be most preferable.

\section{REFERENCES}

Brenchley, P. J., Cocks, L. R. M. Ecological associations in a regressive sequence: the latest Ordovician of the Oslo-Asker District, Norway. - Palaeontology, 1982, 25, $783-815$.

Elles, G. L. The graptolite faunas of the British Isles. - Geol. Assoc. Proc., 1922, $33,168-200$.

Hutt, J. E. The Llandovery Graptolites of the English Lake District. Part 1. London, 1974. 
Rickards, R. B., Hutt, J. E. The earliest monograptid. - Proc. Geol. Soc. London, 1970, $1663,115-119$.

Rickards, R. B., Riva, J. Glyptograptus ? persculptus (Salter), its tectonic deformation, and its stratigraphic significance for the Carys Mills Formation of NE Maine, U. S. A. - Geol. J., 1981, 16, 219-235.

Граница ордовика и силура в Казахстане. Под ред. М. К. Аполлонова, С. М. Бандалетова, И. Ф. Никитина. Алма-Ата, 1980.

Граница ордовика и силура на Северо-Востоке СССР. Под ред. Б. С. Соколова, Т. Н. Корень, И. Ф. Никитина. Ленинград, in print.

Корень Т. Н., Соболевская Р. Ф. Зональное расчлененне пограничных ордовикскосилурийских отложений Омулевских гор по граптолитам. - In: Путеводитель экскурсии в Омулевские горы. Tур VIII. Проблема: «Гранища ордовика и силура». (Тез. докл. сов. геологов.) Магадан, 1979, 42-43.

Корень Т. Н., Орадовская М. М., Соболевская Р. Ф., Чугаева М. Н. Приложение к путеводителю экскурсии в Омулевские горы. Тур VIII. Атлас палеонтологщческих таблиц. Магадан, 1979.

Михайлова H. О находке Glyptograptus persculptus (Salter) в далманитиновых слоях Қазахстана. - ENSV TA Toim. Keemia, Geol., 1970, 19, 177-178.

Михайлова H. Ф. Граптолиты верхнего ордовика и нижнего силура Казахстана. In: Новое в палеонтологии Сибири и Средней Азии. Новосибирск. Тр. ИГиГ, 1973, вып. 47, $14-19$.

Орадовская М. М., Соболевская Р. Ф. Путеводитель экскурсии в Омулевские горы. Typ VIII. Проблема: «Границы ордовика и силура». Магадан, 1979.

All-Union Research Institute of Geology

Received

Feb. 3, 1983

\section{Tatjana KOREN, I. NIKITIN}

\section{KOMMENTAARE ORDOVIITSIUMI JA SILURI PIIRI MÄARAMISE KOHTA}

Ordoviitsiumi ja siluri piiri määramise variantidest - konodonditsoon oldhamensis vôi graptoliiditsoonide extraordinarius, persculptus või acuminatus alumine piir - peetakse parimaks viimast. Selle valiku kasuks kõneleb nii piiri määramiseks kasutatavate graptoliitide taksonoomiline selgus kui ka laialdane levik.

Татьяна КОРЕНЬ, И. НИКИТИН

\section{КОММЕНТАРИИ К ОПРЕДЕЛЕНИЮ ГРАНИЦЫ ОРДОВИКА И СИЛУРА}

В качестве границы ордовика и силура разными авторами предложены подошвы конодонтовой зоны oldhamensis, граптолитовых зон extraordinarius, persculptus и acuminatus. Из них наиболее подходящим положением границы считается последнее, четко определяемое по зональной ассоциации, хорошо изученное во многих регионах мира. 